\section{New Catalysts in Technology of Hydrogenation of Cotton Oil}

\section{N. K. Majidova*}

Bukhara Engineering Technological Institute, Bukhara City, Uzbekistan

"Corresponding author: N. K. Majidova, Bukhara Engineering Technological Institute, Bukhara City, Uzbekistan, Tel: +99865223-78-84; Fax: +99865223-61-97; E-mail: kafedra-03@mail.ru

Received date: February 16, 2016; Accepted date: October 25, 2016; Published date: November 5, 2016

Copyright: $\odot 2016$ Majidova NK. This is an open-access article distributed under the terms of the Creative Commons Attribution License, which permits unrestricted use, distribution, and reproduction in any medium, provided the original author and source are credited.

Keywords: Cottonseed oil; Hydrogenation technology; Hydrogenation catalysts; Stationary and powdered catalyst; Hydrogenated fat food; Quality indicators; Food safety fats; Trans fatty acids isomerization

\section{Introduction}

Improvement of quality of fats can be carried out by change of triglyceride structure of oils and fats in the various ways of their modification. Now the basic methods of modification of oils and fats are technology hydrogenation, hydro inter-esterification and interesterification [1]. In industrial practice most accepted way of catalyst modifications of vegetable oils and fats is the technology of hydrogenation with use of various types of catalysts [2]. Despite large number of the catalysts offered in technology of catalyst modification of cotton oil till this moment there are no concrete recommendations for choice the most effective catalyst allowing considerably to raise quality and to provide food safety of finished food fats. Therefore widely scale researches in the field of development of new technologies and hydrogenation catalysts which main advantage is quality maintenance and food safety catalyst modified fats proceed [3].

\section{Purpose of work}

The work is directed on improvement of quality and maintenance of food safety of fat-oil, received by hydrogenation of cotton oil, by selection of scientifically valid highly effective technologies and catalyst systems, allowing to lower the maintenance a trance-isomerized fat acids and to regulate necessary arrangement of fat acids in triacylglycerides of food fats.

\section{Research course}

Object of research were the refined deodorized cotton oil, powdery and stationary floatable catalyst systems on the basis of nickel, copper and various proctored additives, possessing high hydrogenating properties. Researches on catalyst modifications of cotton oil and studying of the basic kinetic laws of process in flowing conditions in the presence of stationary floatable catalysts is used plant of a high pressure with reactors of columned type [4]. For the analysis and an estimation of quality, the physical and chemical characteristic, food safety of raw materials, intermediate materials, hydrogenated fat-oil and products on their basis are used modern physical, chemical and physical-chemical methods and mathematical processing of the received experimental data $[5,6]$.

\section{Results and Discussion}

In researches on catalyst modifications of cotton oil are used various catalyst systems of new modification. Also were analysed stationary floatable and powdery (Nisosel-8 containing nickel and copper salts) catalysts on the basis of nickel, copper and promrtored additives. The stationary floatable catalysts, containing one and two promrtored additives are analysed. Componential structure of the analysed stationary floatable catalysts is resulted in Tables 1 and 2 .

\begin{tabular}{|c|c|c|}
\hline The catalyst, No & Alloys & Parity of components \\
\hline \multicolumn{3}{|l|}{ Initial } \\
\hline 1 & Nickel-copper-aluminum & $25: 25: 50^{*}$ \\
\hline 2 & Nickel-copper-aluminum & $37.5: 12.5: 50^{* *}$ \\
\hline \multicolumn{3}{|l|}{ Promrtived } \\
\hline $3^{* *}$ & Palladium & 0.1 \\
\hline $4^{* *}$ & Rhodium & 0.5 \\
\hline $5^{\star *}$ & Ruthenium & 0.15 \\
\hline $6^{*}$ & Rhenium & 1.5 \\
\hline $7^{*}$ & Germanium & 1.5 \\
\hline $8^{*}$ & Tin & 1.5 \\
\hline $9^{*}$ & Vanadium & 1.5 \\
\hline
\end{tabular}

Table 1: Componential structure of new types of nickel-copperaluminum floatable stationary catalysts.

\begin{tabular}{|l|l|l|}
\hline The catalyst, No & The additive & The maintenance, \% \\
\hline 10 & Palladium & 0.5 \\
\hline 11 & Ruthenium & 0.5 \\
\hline 12 & Rhenium & 2 \\
\hline 13 & Germanium & 1.5 \\
\hline 14 & Tin & 1.5 \\
\hline 15 & Vanadium & 2 \\
\hline
\end{tabular}

Table 2: Componential structure of new types of nickel-copperrhodium $(0.5 \%)$ - aluminum alloys, promrtored additives.

\begin{tabular}{|l|l|l|}
\hline The catalyst, No & Additives & The maintenance, \% \\
\hline 16 & Rhenium+Germanium & $2.0-2.0$ \\
\hline 17 & Rhenium+Vanadium & $2.0-2.0$ \\
\hline
\end{tabular}




\begin{tabular}{|l|l|l|}
\hline 18 & Rhenium+Tin & $2.0-1.0$ \\
\hline 19 & Germanium+Tin & $2.0-1.0$ \\
\hline 20 & Germanium+Vanadium & $2.0-2.0$ \\
\hline 21 & Rhodium+Vanadium & $0.5-1.0$ \\
\hline
\end{tabular}

Table 3: Componental structure of new types of nickel-copperaluminum of alloys, with the combined combination of two proctored additives.

As the most effective powdery catalyst it is used catalyst "Nysosel-800" made by firm Engelhard in Holland [7]. In researches are studied nickel-copper-aluminium (25.0:25.0:46.0-48.5) alloys with the joint combination of two promrtored additives (Table 3 ). Catalys hydrogenation of cotton oil were carried out in identical technological modes (Table 4) at which the basic properties of stationary floatable catalysts are established. The basic physical and chemical characteristics of catalyst "Nysosel-800" are resulted in Tables 5 and 6.

\begin{tabular}{|l|l|l|}
\hline Parameters of conditions of hydrogenation & Unit of measure & Value \\
\hline Temperature & ${ }^{\circ} \mathrm{C}$ & 200 \\
\hline Pressure & $\mathrm{kPa}$ & 300 \\
\hline Volume velocity of feed of raw materials & $\mathrm{h}^{-1}$ & 1 \\
\hline Volume velocity of feed of hydrogen & $\mathrm{h}^{-1}$ & 60 \\
\hline Catalyst volume & $\mathrm{ml}$ & 1000 \\
\hline The average size of particles of the catalyst & $\mathrm{mm}$ & 6 \\
\hline
\end{tabular}

Table 4: Conditions of an estimation of hydrogenating properties of new types of floatable stationary catalysts.

\begin{tabular}{|l|l|}
\hline Component & Percentage parity \\
\hline Nickel 7440-02-0 & 15 \\
\hline Aluminate of nickel 12004-35-2 & 10 \\
\hline Sulphide of nickel 12035-72-2 & 2 \\
\hline Hydrogenated vegetable oil 68334-28-1 & not established \\
\hline
\end{tabular}

Table 5: Componential structure of catalyst "Nysosel-800".

Research of influence of temperature for velocity of saturation of cotton oil at presence of non-promotor and promotor nickel-copperaluminum catalysts carried out at following conditions: pressure 300

$\mathrm{kPa}$, velocity of feed of hydrogen of $60 \mathrm{ml} \mathrm{h}^{-1}$, volume velocity of feed of oil $1.2 \mathrm{~h}^{-1}$. Results of research are presented at Table 7 .

\begin{tabular}{|l|l|}
\hline Physical condition & Firm, granules \\
\hline Color & The black \\
\hline Smell & Has no \\
\hline Melting temperature & Nearby $60^{\circ} \mathrm{C}$ \\
\hline Disintegration temperature & Above $300^{\circ} \mathrm{C}$ \\
\hline Volume density & $700-800 \mathrm{~kg} / \mathrm{m}$ \\
\hline Solubility & not dissolved \\
\hline Self-ignition temperature & $350^{\circ} \mathrm{C}$ \\
\hline
\end{tabular}

Table 6: Physical and chemical properties of catalyst "Nysosel-800".

\begin{tabular}{|l|l|l|l|l|}
\hline \multirow{2}{*}{ Temperature, ${ }^{\circ} \mathbf{C}$} & \multicolumn{2}{|l|}{ The catalyst, No } \\
\cline { 2 - 5 } & $\mathbf{2}$ & $\mathbf{5}$ & $\mathbf{2 0}$ & $\mathbf{2 1}$ \\
\hline 120 & $\Delta$ I.h. $\% \mathrm{I}_{2}$ & $\Delta$ I.h. $\% \mathrm{I}_{2}$ & $\Delta$ I.h. $\% \mathrm{I}_{2}$ & $\Delta$ I.h. $\% \mathrm{I}_{2}$ \\
\hline 140 & 19 & 25 & 27 & 28 \\
\hline 160 & 27 & 32 & 40 & 42 \\
\hline 180 & 33 & 38 & 42 & 43 \\
\hline 200 & 38 & 40 & 45 & 46 \\
\hline 220 & 44 & 46 & 53 & 54 \\
\hline
\end{tabular}

Table 7: Dependence of velocity of saturation of cotton oil on temperature on stationary catalysts.

As we see from Table 7, with rise in temperature velocity of saturation increases, thus intensive growth of velocity is observed at $200^{\circ} \mathrm{C}$, even at $120-180^{\circ} \mathrm{C}$. Apparent activation energy is approximately equal to $15 \mathrm{~kJ} / \mathrm{mol}$. At more heat this size decrease even more sharply that specifies in limitation of process by hydrogen diffusion [8]. Pressure of hydrogen has the greatest influence of fat-oil qualitative measures in the course of continuous hydrogenation. In these conditions the greatest influence on selectivity of process renders a combination of the raised temperatures to enough high volume velocity on oil. In this connection, particular interest has data, received at continuous operation of hydrogenation plants (Tables 8-10).

\begin{tabular}{|c|c|c|c|c|c|c|c|c|}
\hline \multicolumn{2}{|c|}{ Modification conditions } & \multicolumn{5}{|c|}{ Fatty-acid structure } & \multirow{2}{*}{$\begin{array}{l}\text { Factor of selectivity, } \\
\%\end{array}$} & \multirow{2}{*}{$\begin{array}{l}\text { The maintenance of trance- } \\
\text { acids, } \%\end{array}$} \\
\hline Pressure, $\mathrm{kPa}$ & Velocity of feed of oil, $h^{-1}$ & 14:0 & $16: 0$ & $18: 0$ & $18: 1$ & $18: 2$ & & \\
\hline 100 & 1.6 & 0.6 & 22.0 & 6.9 & 53.9 & 16.6 & 91.2 & 17 \\
\hline 300 & 1.6 & 0.6 & 21.7 & 8.0 & 51.4 & 18.3 & 90.0 & 15 \\
\hline 300 & 1.1 & 1.0 & 22.4 & 6.0 & 63.6 & 7.0 & 94.8 & 13 \\
\hline
\end{tabular}


Citation: Majidova NK (2016) New Catalysts in Technology of Hydrogenation of Cotton Oil. J Exp Food Chem 2: 118. doi: 10.4172/2472-0542.1000118

Page 3 of 3

\begin{tabular}{|l|l|l|l|l|l|l|l|l|}
\hline 100 & 1.1 & 1.7 & 22.2 & 8.2 & 50.3 & 18 & 89.3 & 14 \\
\hline
\end{tabular}

Table 8: Reception of fat-oil for confectionery products on recycled and experimental (120) catalyst N 21, promrtored vanadium.

\begin{tabular}{|l|l|l|l|l|}
\hline lodic number, $\% \mathrm{I}_{2}$ & The maintenance of conjugate diene, $\%$ & Acid number, $\mathbf{~ m g ~ K O H / g}$ & Temperature of melting, ${ }^{\circ} \mathrm{C}$ & Hardness, $\mathbf{g} / \mathbf{c m}$ \\
\hline 81.5 & 0.81 & 0.25 & 36.6 & 400 \\
\hline 75.8 & 0.82 & 0.26 & 37.0 & 500 \\
\hline 66.7 & 0.94 & 0.29 & 37.6 & 480 \\
\hline 67.6 & 0.80 & 0.31 & 36.3 & 360 \\
\hline
\end{tabular}

Table 9: Technical and chemical characteristic of fat-oil, received on catalyst N 21.

\begin{tabular}{|c|c|c|c|c|c|c|c|}
\hline \multicolumn{3}{|c|}{ Modification conditions } & I.n $\% \mathrm{~J}_{2}$ & The maintenance of & \multirow{2}{*}{$\begin{array}{l}\text { Acid number, } \\
\mathrm{mg} \mathrm{KOH/g}\end{array}$} & \multirow{2}{*}{$\begin{array}{l}\text { Temperature of } \\
\text { melting, }{ }^{\circ} \mathrm{C}\end{array}$} & \multirow{2}{*}{ Hardness, $\mathrm{g} / \mathrm{cm}$} \\
\hline Temperature, ${ }^{\circ} \mathrm{C}$ & Pressure, $\mathrm{kPa}$ & $\begin{array}{l}\text { Velocity of } \\
\text { feed of oil, } \mathbf{h}^{-1}\end{array}$ & & & & & \\
\hline 200 & 300 & 1.8 & 74.1 & 11 & 0.2 & 34.5 & 420 \\
\hline 200 & 300 & 1.5 & 72.1 & 14 & 0.21 & 36.1 & 500 \\
\hline 200 & 100 & 1 & 64.2 & 18 & 0.27 & 37.2 & 540 \\
\hline 180 & 100 & 1 & 63.7 & 19 & 0.29 & 37.1 & 600 \\
\hline 180 & 100 & 1.2 & 66.4 & 21 & 0.35 & 38.3 & 620 \\
\hline
\end{tabular}

Table 10: The characteristic of fat-oil, received by continuous catalyst modification of cotton oil on recycled and trained during $800 \mathrm{~h}$ catalyst $\mathrm{N}$ 21 (selectivity of process of $94-99 \%)$.

\section{Conclusions}

It is established that the optimal catalyst systems for production of firm food fat-oil of high-quality and food safety are powdery and developed stationary floatable catalysts on the basis of nickel, copper and promotor additives. Such catalyst systems have allowed to lower quantity of trance-isomerized fat acids in fat-oil to $5-7 \%$ and to provide maintenance constancy of linoleic acids. The most comprehensible technological modes of manufacture of the highquality hydrogenated fats were temperature $180^{\circ} \mathrm{C}$, pressure $100 \mathrm{kPa}$ and volume velocity of feed of oil $1.2-1.5 \mathrm{~h}^{-1}$. Such conditions have allowed lowering the quantitative maintenance of trance-isomerized mono-nonsaturated fat acids in food fat-oil.

\section{References}

1. Arutyuyan NS (1999) Technology of fat processing. In: Arutyuyan NS. Pishepromizdat; 1999. p. 452.

2. Tovbin IM, Melamud NL, Sergeyev AG (1981) Hydrogenation of fats. In: Light and Food Industry; 1981. p. 246.
3. Akramov OA (2008) Modification of cotton oil with efficient of the catalyst. In: Abstract thesis of candidate of technical sciences. TashCTI: Tashkent. 2008. p. 26.

4. Majidova NK (2010) Improving of quality and ensuring of food safety of hydrogenated fat obtained by hydrogenation of cotton oil. In: N.K. Majidova. Abstract thesis of candidate of technical sciences. TashCTI; 2010. p. 26.

5. Manual of methods of research, technical-chemical control and production accounting of fat-and-oil industry. 4: 1967-1989.

6. Adler YP, Markova YV, Granovskiy YV (1976) Planning of experiment in the search for optimal conditions. In: Nauka; 1976.

7. Majidova NK, Akramov OA, Xujanov IX, Majidov KH (2007) Improving of technology of catalytic modification of cotton oil. Collected papers of the Republican Scientific and Technical Conference, Tashkent, 279-281.

8. Majidov KH (1987) Research and perfection of technology of hydrogenated cotton oil on modified alloyed stationary catalysts. In: Majidov KH. Abstract thesis of doctor of technical sciences; 1987. p. 48. 